Krzysztof STOPKA

iD https://orcid.org/0000-0003-4971-2650

UNiWERSYTET JagiellońsKi, KRAKów

\title{
ODNALEZIONA KSIĘGA GMINY ORMIAŃSKIEJ W ZAMOŚCIU
}

Gmina ormiańska w Zamościu powstała w latach 80. XVI wieku. Przywilej na osadzanie się otrzymali Ormianie w 1585 roku od Jana Zamoyskiego, kanclerza Królestwa Polskiego i hetmana wielkiego koronnego. W 1589 roku Zamoyski zezwolił na powołanie osobnego sądu ormiańskiego składającego się z wójta i ławników. Urząd ten został zorganizowany według wzorów istniejących w Kamieńcu Podolskim. Sprawy sądowe między Ormianami były rozstrzygane według prawa magdeburskiego i statutów prawa ormiańskiego (Statuta iuris armenici) zatwierdzonych przez króla Zygmunta I na sejmie w Piotrkowie w 1519 roku.

Protokoły posiedzeń sądu były wpisywane do ksiąg pod nazwą: Acta civilia advocatalia et scabinalia iuris Armenici privilegiati Zamoscensis lub Akta wójtowskie uprzywilejowanego Prawa Ormiańskiego Zamojskiego. Są to księgi ormiańskiego sądu wójtowsko-ławniczego. Spis z roku 1680 wymieniał jako najstarszą księgę z lat 1598-1611, ale niestety się nie zachowała. Do tej pory znanych było siedem ksiąg tego sądu - spisanych w języku polskim i przechowywanych w Archiwum Państwowym w Lublinie (częściowo dostępnych on-line) w zespole Akta m. Zamościa. Zachowały się księgi za lata: 1 (1626-1648); 2 (1642-1643); 3 (1649-1659); 5 (1669-1674); 6 (1680-1685), 7 (1685-1689) oraz 8 (1690-1700).

W 2017 roku w Narodowym Archiwum Historycznym Białorusi (Нацыянальны гістарычны архіў Беларусі) w Mińsku odnalazła się księga zamojska prowadzona od 23 października 1660 do 23 września 1668 roku (tzw. starego stylu), a więc brakująca księga 4 (fond 1807, opis 1, dieło 1). Pierwotnie liczyła 258 numerowanych kart, ale dzisiaj jest ich 242. Do Mińska trafiła podczas po- 
wojennego dzielenia archiwaliów między Polskę a Związek Sowiecki, prawdopodobnie na skutek błędnego zakwalifikowania miejsca wytworzenia. W obecnych granicach Białorusi znajduje się nawet kilka miejscowości o nazwie Zamość lub Zamoście, które można było pomylić z Zamościem w Polsce. Księga została zeskanowana, a następnie udostępniona uczonym w wyniku starań p. Armena Checzojana z Fundacji Aniv (Фонд развития и поддержки арменоведческих исследований «АНИВ»).

Do ormiańskich ksiąg sądowych wpisywano sprawy sporne i niesporne, akta woli prywatnej, inwentarze, testamenty, działy rodzinne, umowy zaręczynowe itd. Księgi te zawierają akta obioru władz ormiańskich, spisy podatkowe, konskrypcje, zarządzenia właścicieli miasta, kopie dekretów sądów zamkowych i trybunalskich zamojskich. Księgi mają duże znaczenie m.in. dla badań ustrojowych, społecznych, handlowych, genealogicznych oraz kościelnych. Szczególnie cenne są dla odtworzenia organizacji ormiańskiej gminy i funkcjonowania sądownictwa. Niestety nie są znane księgi sądu ormiańskiego z Zamościa po 1700 roku. 


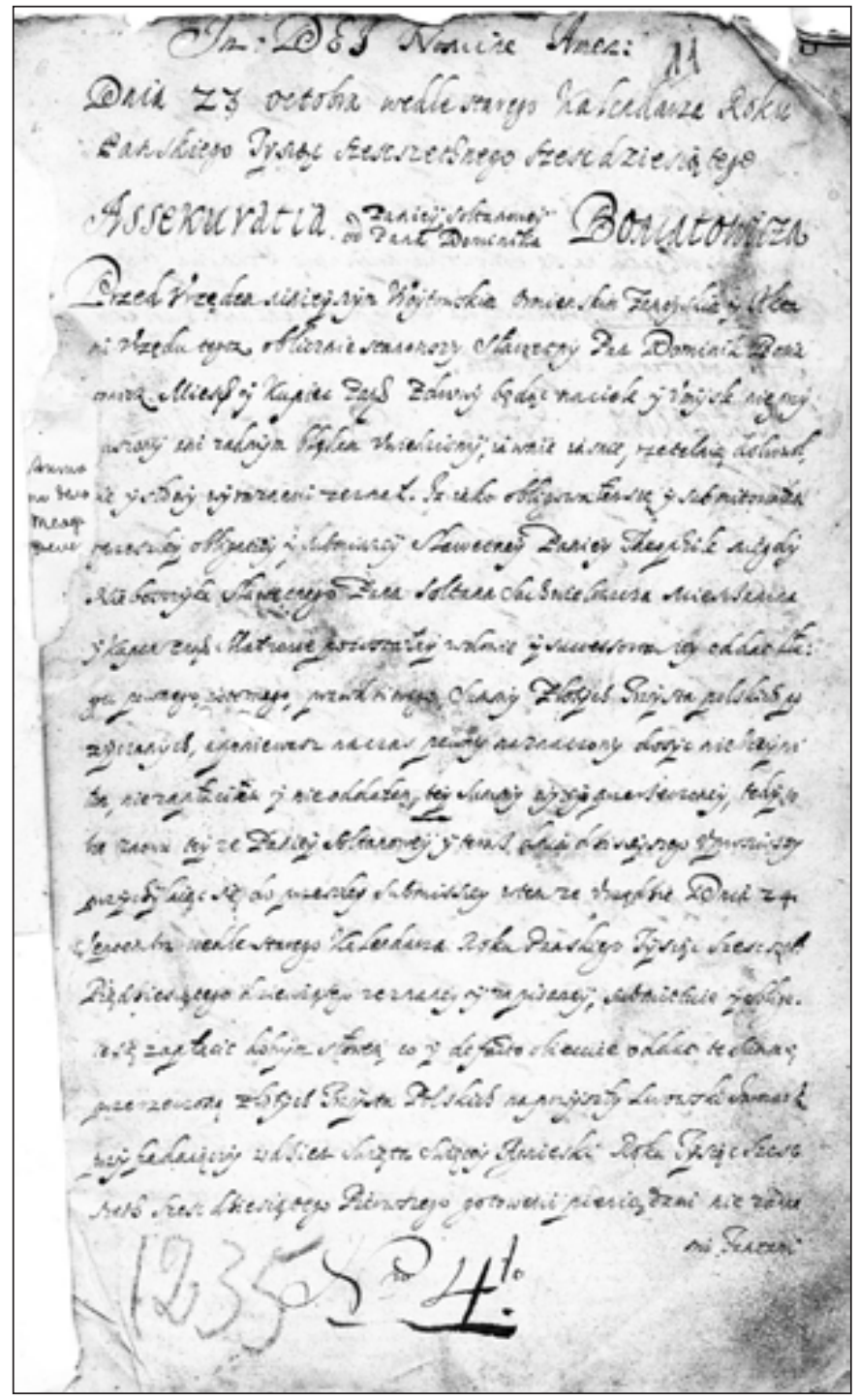

Karta z księgi gminy ormiańskiej w Zamościu, odnalezionej w Narodowym Archiwum Historycznym Białorusi w Mińsku 


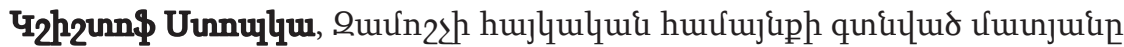

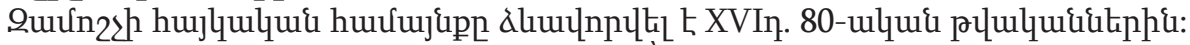

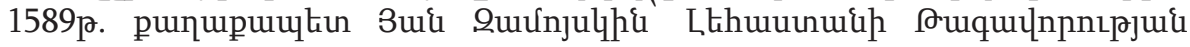

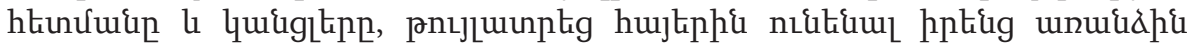

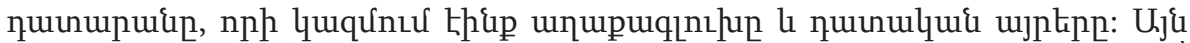

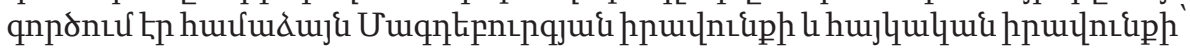

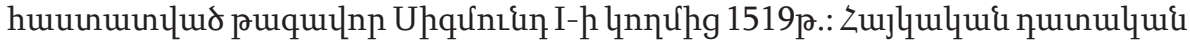

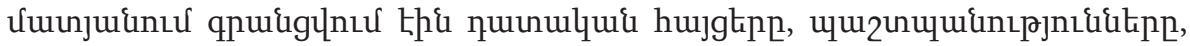

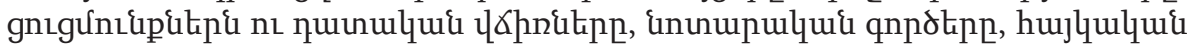

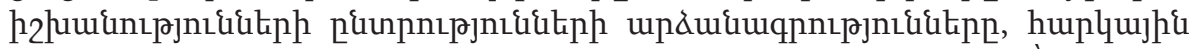

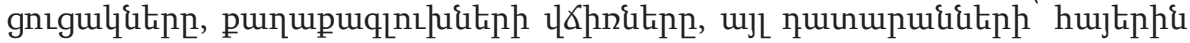

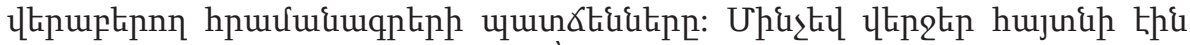

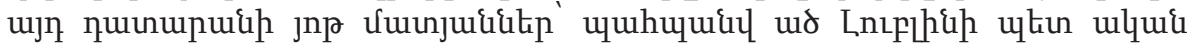

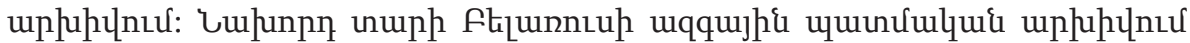

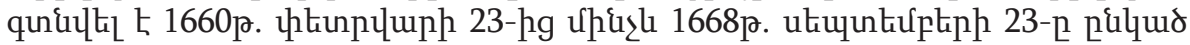

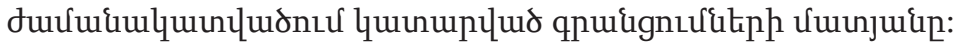

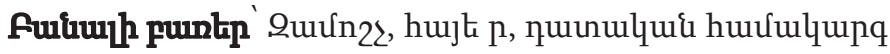

\section{Krzysztof Stopka, A Newly Found Book of Armenian Community in Zamość}

The Armenian community in Zamośc developed in the 80s of the $16^{\text {th }}$ century. In 1589 Jan Zamoyski, a hetman and chancellor of The Kingdom of Poland, as well as the city owner, allowed for creating an independent Armenian court with its vogt and jurors. The court proceeded by Magdeburg law, which was in force in Zamość, and by Armenian law which had been approved by King Sigismund I in 1519. The Armenian court acts record plaints, defences, testimonies, sentences, notary acts, election protocols of the Armenian selfgovernment, tax rolls, city owners edicts, copies of sentences which concerned Armenians from other courts. Until very recently there has been only seven books of this kind, all stored in the National Archive in Lublin. Last year another book kept between 23 October 1660 and 23 September 1668 was found in the National Historical Archive in Minsk in Belarus.

Keywords: Zamość, Armenians, judiciary 